\title{
Why does Europe have a drinking problem
}

\author{
Citation for published version (APA):
}

Anderson, P. D. (2012). Why does Europe have a drinking problem. Maastricht University. https://doi.org/10.26481/spe.20120530pa

Document status and date:

Published: $30 / 05 / 2012$

DOI:

10.26481/spe.20120530pa

Document Version:

Publisher's PDF, also known as Version of record

\section{Please check the document version of this publication:}

- A submitted manuscript is the version of the article upon submission and before peer-review. There can be important differences between the submitted version and the official published version of record.

People interested in the research are advised to contact the author for the final version of the publication, or visit the DOI to the publisher's website.

- The final author version and the galley proof are versions of the publication after peer review.

- The final published version features the final layout of the paper including the volume, issue and page numbers.

Link to publication

\footnotetext{
General rights rights.

- You may freely distribute the URL identifying the publication in the public portal. please follow below link for the End User Agreement:

www.umlib.nl/taverne-license

Take down policy

If you believe that this document breaches copyright please contact us at:

repository@maastrichtuniversity.nl

providing details and we will investigate your claim.
}

Copyright and moral rights for the publications made accessible in the public portal are retained by the authors and/or other copyright owners and it is a condition of accessing publications that users recognise and abide by the legal requirements associated with these

- Users may download and print one copy of any publication from the public portal for the purpose of private study or research.

- You may not further distribute the material or use it for any profit-making activity or commercial gain

If the publication is distributed under the terms of Article $25 \mathrm{fa}$ of the Dutch Copyright Act, indicated by the "Taverne" license above, 


\section{"WHY DOES EUROPE HAVE A DRINKING PROBLEM"}

\section{Dr. Peter Anderson}

Inaugural lecture for the appointment as extraordinary professor Alcohol and Health in the Faculty of Health, Medicine and Life Sciences, Maastricht University.

Wednesday 30 May 2012 at 16:30

Vice Rector, dear friends and dear colleagues, in 1997 a seventeen year old freshman, unknowing of the consequences, perhaps fool hardy, and certainly under peer pressure, consumed a full bottle of spirits. Next morning, he was found dead in his bed. This is a tragedy of unimaginable feeling to his parents, his brother, his wider family, and his friends. This death led to a chain of events, some fast, and some slow, and a private donation from a very thoughtful person, to me being here. It has also led to the creation of the Ronald Pfeiffer Knowledge Centre on Alcohol and Health. Actually, a similar tragedy led to me being in this field. As a trainee general practitioner at Oxford, a student also died of an overdose. I undertook a survey of the drinking habits of Oxford University students (Anderson 1984), which started me on my career of alcohol research.

\section{About myself}

My tutorials at Magdalen College, in Oxford, took place below the room of AJP Taylor, one of Europe's greatest $20^{\text {th }}$ Century historians, particularly on the origins of the Second World War (Taylor 1991). As a historian, he bought history to the people. For a BBC series on history, he would stand in front of the camera, and talk, unscripted for 30 minutes. I cannot do the same, as I need my notes. And, with no camera, I will talk for a little longer - I have been given clear instructions that I should deliver a lecture - so, this is what you will get.

Perhaps, having started my life in Oxford, it is best to complete my story. In Oxford, I trained to be a doctor, then a general practitioner, and then a public health specialist, a different concept to many countries. In England, it is a five year specialty training. I was a research fellow at Oxford University, and then directed a Department of Health funded centre on health promotion in primary health care. Then, I worked for the European Office of the World Health Organization on alcohol and tobacco policy. After that, I have led an independent career, bringing science to policy across a range of public health issues for the European Commission, WHO, and several governments and think tanks around the world.

Currently, I oversee research in three major European projects valued at eighteen million Euros. These include the AMPHORA project on alcohol policy [www.amphoraproject.net], the ODHIN project on translational research into everyday clinical practice, using alcohol as an example [www.odhinproject.eu], and the ALICE RAP project which is reframing our understanding of addictions in a well-being frame, and redesigning addictions governance [www.alicerap.eu]. Maastricht University is well-represented in all three projects.

\section{Europe's drinking problem}

Returning to our seventeen year old. The tragedy is that he is not alone. Each year in the European Union 120,000 deaths amongst 15-64 year olds are due to alcohol (Shield et al 2012). This is an important age of human capital formation and maturation in terms of educational achievement and working life. One hundred and twenty thousand is one in eight of all deaths. These deaths are simply because we, in Europe, drink too much. Every man and woman aged 15 years or more drinks on average about 12.5 litres of pure alcohol a year, nearly $30 \mathrm{~g}$, three drinks a day, more than double 
the world's average (Shield et al 2012). One in eight is the figure for the European Union as a whole. Netherlands is doing better - the figure is about 1 in 16. But, go further east, and you will find unimaginable tragedies. In Russia, outside of the European Union, more than half of all deaths amongst 15-54 year olds are due to alcohol (Zaridze et al 2009). This is a crisis of more than humanitarian proportions - and, no one seems to be doing anything about it.

But the real tragedy of this tragedy is that it can be largely prevented. But, then we humans are not very good at preventing tragedies. Many of you will know the story of Asgard and the Gods recently retold by the English author, AS Byatt with the title Ragnarok (Byatt 2011). I carry this book with me at all times. It is a story about the gods, who simply argue amongst themselves, without even noticing that they are bringing on their own destruction. As humans, with, for example climate change (King 2011), we risk being very good at that too.

In the rest of this lecture, I will consider five sectors, and reflect on their contribution to these alcohol caused deaths, and to their contribution to preventing them. Ideally, we would like an alcohol, or addictions, or a health footprint (Harrison et al 2011; Anderson et al, submitted). A water footprint tells us how much water we use. A carbon dioxide footprint tells us how much carbon dioxide we produce. We are good at looking at the contribution of risk factors to ill-health, for example alcohol's contribution to disability adjusted life years, a summary measure of ill-health and premature death, where alcohol is the world's number one risk factor for the 15-59 year old age group (World Health Organization 2011). But, we do not have a footprint to measure the impact of action by industry, or by government, or by municipality, or what I put in my shopping basket on alcohol's impact on health and well-being (Anderson et al 2011). A major research strand that I am coordinating in the ALICE RAP project is doing just that.

Here is the summary of the rest of what I am going to say:

First, the alcohol industry as a whole does not have the incentives to reduce consumption that will save these deaths; however, they could alter their product, which, ultimately, is the cause of these deaths. Second, one should be highly suspicious of politicians and the alcohol industry working together - and, there are too many examples of this; ultimately, most governments and international governmental bodies have failed to regulate the industry's operating environment effectively; so, too, they are responsible for these deaths. Third, with a few notable exceptions, most NGOs, and particularly those working in the European environment, who should be the voice of the people, have tended to appease both the industry and governmental bodies, and so, too, are responsible for these deaths. Fourth, all of us, citizens need to be more active in our demands on our politicians, who are, after all, through the taxes we pay, our employees, in reducing these deaths; our own behaviour can also have a huge impact on the behaviour of others. And, fifth, as scientists, we have a lot of knowledge about what to do, and we should be more proactive in dialogue with policy advisors and politicians in trying to encourage what should be done done.

In making this summary, I will have offended some people, and, in expanding on them in more detail, I, no doubt, will offend more, perhaps also some of you in the audience. But, I offer no apology about this. We are, after all, talking about the tragedies of preventable deaths.

And, of course, what I have to say is not special (Wiist 2010). One could have given a similar lecture certainly about tobacco in the past, or about the oil industry and climate change now, or about banks and the economic crisis. They are all about the need to align incentives for human well-being rather than profit (Anderson et al 2011). 


\section{Alcohol industry}

So, let's come back to the first of my big five, the alcohol industry. The industry has said that alcohol policy should focus on heavy drinkers (Anderson \& Baumberg 2006a). But, do not be fooled by this this is from where they get their profit (Baumberg 2009). Corporate social responsibility activities are a communication device to delay policy - and, they work. Take self-regulation of advertising as an example. During April 2012, leading producers from the beer, wine and spirits sectors launched an "initiative to strengthen independent advertising self-regulatory schemes for alcohol beverage marketing by establishing a set of common, rigorous standards for their marketing communications throughout the European Union" [http://www.wfanet.org/en/advocacy/responsible-marketingpact]. No doubt, as the industry themselves say, it is difficult for the industry to come together collectively on a self-regulatory code - but, this is irrelevant, and just a delaying tactic to avoid stronger advertising policy. All the evidence shows that self-regulation does not and cannot work (Casswell 2012). The Internet and YouTube are good examples here. It is through social media that alcoholic beverages are widely promoted. Such media make self-regulation and withdrawal of advertisements that break advertising codes irrelevant, as the advertisements simply live on through social media, accessible to all (Anderson et al 2012).

There are actions that the alcohol industry can take. In the United Kingdom alcohol strategy, which was launched during March 2012, a commitment was called for the alcohol industry to remove 8 billion grams of alcohol from the market by the year 2015 (HM Government 2012). This is alcohol simply not produced - no one is drinking it, and this commitment will save lives (Anderson 2012a). In fact, Heineken, your own great Dutch brewer, has already been doing this in the United Kingdom market for one of their popular beer products - by reducing its strength. I met and talked with the Global Director for Public and Governmental Affairs for Heineken, at a European Commission meeting during April 2012 [http://ec.europa.eu/health/alcohol/docs/ev 20120418 mi en.pdf]. He seemed dismissive of this approach and not very proud of it, thinking it only relevant to the UK market. Well, he should be proud of it and the model should be expanded to other markets.

But, health initiatives by the food and beverage industries are not easy. PepsiCo's CEO wanted to redirect its products to be healthier. But, the shareholders did not like this and said that there was no profit in it. They instructed her to change course or stand down. She changed course. We all share a bit in what shareholders do, don't we - our pensions.

We have a big research strand in ALICE RAP on corporate social responsibility and what it really means [http://www.alicerap.eu/images/Work\%20Catalogue/AR Piece BaumbergCuzzocrea 2.pdf]. In Maastricht, as part of the ALICE RAP project, we are also studying the impact of marketing cues on brain function in adults, including those undergoing treatment for alcohol use disorders http://www.alicerap.eu/images/Work\%20Catalogue/AR Piece Ramaekers et al.pdf].

\section{Politicians}

Let's move to the second of the big five, politicians. The Economist once wrote that the business of business is business (Crook 2005). It should meet the needs of its shareholders and not meddle in policies that impact on human well-being. That is the role of governments who are answerable to the people, and who need to regulate the environments in which businesses operate, when it comes to reducing externalities and regrettables. The Economist continued by writing be highly suspicious when the two work together on policy. Indeed. Take the UK Government under Tony Blair. He was great friends with Diageo and launched the Alcohol Harm Reduction Strategy for England from Diageo's headquarters. And, no wonder that the contents included the policy approaches favoured by the industry, those which had been proven not to work, and little of those that would have made a difference (Anderson 2007). No wonder that the Alcohol Harm Reduction Strategy for England was known as England's AHRSE. 
Take the European Policy Centre (EPC), invited by DG SANCO, the European Commission's Health and Consumer Directorate to broker the content of the Commission's Communication on alcohol between the alcohol industry and the NGOs and the public health community (Baumberg \& Anderson 2007). The EPC sounds like a think tank, doesn't it? But, no, it is a lobby organization paid by many industries, including the alcohol and tobacco industries. In fact, the tobacco papers show that the EPC and its then Director were paid by the tobacco industry to lobby the EU to ensure that all EU policy discussions should, by law, involve the relevant industry (Smith et al 2010). Remember the Economist. Be suspicious then of the Communication on alcohol. And, you would be correct the word education appears 14 times, and the word price once, as in price promotions (Gordon \& Anderson 2011). Science shows that education on its own cannot change drinking behaviour, whereas price is the most effective and cost effective of all policy options to reduce consumption and alcohol-related harm, even amongst young and heavy drinkers. This evidence was all available to the Commission at the time, even in one of their own publications (Anderson \& Baumberg 2006b).

In the ALICE RAP project, we have a major research strand analysing these webs of influence and their impact [http://www.alicerap.eu/images/Work\%20Catalogue/AR Piece MillerHarkins.pdf].

\section{Non-governmental organizations}

Now, the third of the big five - non-governmental organizations (NGOs). These should be the voice of the people, and, in many cases, NGOs truly are. In the alcohol field, there are shining examples at the country level - for example, here in the Netherlands, STAP, the Dutch Institute for Alcohol Policy [http://www.stap.nl/en] has led the way in arguing for a ban on alcohol advertising; in Scotland, SHAAP, Scottish Health Action on Alcohol Problems [http://www.shaap.org.uk/] has led the way in calling for the introduction of a minimum unit price for alcohol.

But, there are many examples at the global and European levels where NGOs have failed us. Last year, was the United Nations High Level Meeting on non-communicable diseases (NCDs) [http://www.un.org/en/ga/president/65/issues/ncdiseases.shtml]. Despite alcohol being a major risk factor for NCDs, cancers and cardiovascular diseases amongst others (Anderson 2012b), the NGO community failed to get alcohol taken seriously in the HLM's resolution and discussions (Lancet Oncology 2011).

Nearer at home, in Europe, the European NGOs have apparently appeased the alcohol industry and condoned the cosy relationship between the European Commission and alcohol producers. You can observe this by attending the meetings of the Alcohol and Health Forum and reading the notes of the meetings [http://ec.europa.eu/health/alcohol/forum/index_en.htm], which have also been formally studied (Gordon \& Anderson 2011). The Alcohol and Health Forum is a stakeholder platform to gain commitments from economic operators and non-governmental organizations on actions to reduce alcohol-related harm [http://ec.europa.eu/health/alcohol/forum/index en.htm]. Analysis of commitments by the industry and NGOs alike shows them to be meaningless and non-evidence based (Celia et al 2010). By being part of the process, NGOs condone it, and, analysis of the notes shows that they do not effectively challenge the industry viewpoint [http://ec.europa.eu/health/alcohol/docs/forum flash 26042012 en.pdf]. This appeasement delays more effective approaches, thus inevitably leading to more preventable deaths.

Many will not like what I am about to say, but, even in this country, I am told that the caner organizations do not take alcohol seriously. Alcohol is classified by the International Agency for Research on Cancer, the global authority and classificatory body on carcinogens as a class I cancer (International Agency for Research on Cancer 2010). Simply put, this means that alcohol causes cancer, and, by being defied as a carcinogen, any dose is a risk. Just take female breast cancer as an 
example. There is a linear dose response relationship between consumption and risk, with increased risk at even half a drink ( $5 \mathrm{~g}$ alcohol) a day (see Anderson 2012b). Not only that, but relapse after treatment increases in a dose response relationship, with increasing levels of alcohol consumption (Kwan et al 2010). For 15-64 year old women in the European Union, one third of all alcohol-related deaths are due to cancer (Shield et al 2012). Yet, I am told that the cancer organizations in this country are not willing to endorse a statement to women that, to avoid the risk of breast cancer or relapse in those who have had the disease, do not drink alcohol.

\section{Us, citizens}

And, now to the fourth of my big five - all of us, citizens. Our own drinking has a huge impact on our friends and family. The Framingham network studies show that the more you are exposed to nondrinkers in one year, the more likely you are to become yourself a non-drinker in subsequent years (Rosenquist et al 2010). Likewise, the more you are exposed to a heavy drinker in one year, the more likely you are to become a heavy drinker yourself in subsequent years. I am very happy to say that these networks also matter for happiness and cooperative behaviour. The happier and more cooperative you are, the happier and more cooperative people related to your friends and family are, over a wide range of influence and time (Fowler et al 2008; 2010).

As citizens, we can make our views more known to our politicians. Non-smokers complained about exposure to second hand smoke. We can also complain about health harms due to others' alcohol consumption - particularly, form traffic injuries, violence and low birth weight. It is not huge, but some 1 in 20 of all European Union ill-health and premature death due to alcohol comes from harms from someone else's drinking (Shield et al 2012).

In the ODHIN project, we are studying doctors, to identify the best ways to get them to deliver more brief advice for more heavier drinkers [http://www.odhinproject.eu/project-structure/workpackage5.html]. One of the reasons we do this is to try to engage doctors to be more active as policy advocates, because they are role models and have set good examples. When I trained as a doctor, a person with alcohol dependence was defined as someone who drank more than their doctor. But, since then, British doctors have dropped from being one of the occupations with the highest death rates from liver cirrhosis (alcohol being the major cause) to one with the lowest - they have clearly got the message (Romeri et al 2007).

\section{Scientists}

And, so, to five of five, scientists, many of us. There are many scientists who would prefer to sit at their desks and not get involved in policy. But, I would argue that you cannot afford to do that. And, you see a big change here, throughout all of science. If you are a regular reader of the journal, Nature, you will read that this happens a lot with some of the big issues of the day, climate change, sustainability, oil reserves and so on, where scientists come out of their offices and actively engage policy advisors and politicians in science policy dialogues (Nature 2012; also, see Sutherland et al 2012).

In the ALICE RAP project, along with the RAND Corporation, we recently did that over pricing policy and the UK alcohol strategy [http://www.alicerap.eu/images/Alcohol\%20pricing\%20and\%20related\%20harms\%20Seminar 23-212 Summary\%20notes.pdf]. We heard that there was some hesitancy over the forthcoming alcohol strategy. And so we wrote to the Prime Minister's Cabinet Office, saying could we talk. And, in the end, we had a meeting of a collection of the world's top scientists and representatives of the Cabinet Office, health department, treasury and home office that deals with crime. Some say that the launch of the strategy was delayed because of this meeting, and that the meeting gave the strategy a great push in the right direction. 
Policy making is a constant drip drip of the evidence, and then a great push when a window of opportunity opens. Perhaps, we would do well to study how we could better open more windows and open them wider. We are familiar with brief advice programmes for providers and patients. What about brief advice for politicians - it is the famous elevator pitch - you are in the elevator with a politician, what do you say?

Some of the things you can say are the best buys (World Economic Forum 2001) - increase the price of alcohol and introduce a minimum price per gram of alcohol, reduce availability and ensure that the public's health and well-being are an objective of licensing policy to sell alcohol; and, ban all forms of commercial communications. It is interesting that the new UK alcohol strategy did two of these - it failed on commercial communications. Importantly, it made clear that the strategy was on alcohol, and not on harmful drinking, as some strategies are harmfully called, and it introduced a minimum price per gram of alcohol sold. And, finally, it got the commitment, as I said before, to remove 8 billion grams of alcohol from the market. These will be gone by 2015. No one anywhere will drink them. It will be done by reducing the strength of popular beers a little bit, incentivized by taxing beer proportional to its alcohol content.

\section{Conclusion}

Ladies and gentleman, I am coming to an end. I started by telling us that a 17 year old died a tragic death from a drug overdose - that drug was alcohol. I noted that this was a symptom and, indeed a consequence of, for sure, that Europe has a drinking problem. I have considered some of the causes and solutions to that problem. I have noted that with, perhaps the exception of the UK government's strategy, there are no incentives for the alcohol industry to solve this problem. Everything tells us that the opposite is the case. I have noted for the most part that politicians and intergovernmental bodies fail to regulate the environment in which the alcohol industry operates in the interest of human health and well-being. I have noted that, with some notable exceptions at the country level, NGOs seem complicit in this process. Having offered three examples of doom and gloom, I have reminded us as citizens that we can be more active in our demands to the political elite, and to set examples in our own behaviour, as British doctors have done. Finally, I have suggested that we, as scientists, can be more active in initiating science policy dialogue and the evidence across a range of topics demonstrates that this can be effective.

Before closing, there are, of course, some of you in the audience to whom I would like to say thank you. Clemens Hosman, who, some twelve years ago, in Paris, introduced me to my dear wife Eva, who, unfortunately cannot be here, as she is presently in another region of the world trying to persuade that region's elite to do more for health. Clemens' introduction led me to move to Nijmegen, where Eva was working, and complete my PhD thesis, started many years ago in Oxford. This led me to meet Onno van Schayck in the stop smoking partnership, and now head of CAPHRI, and instrumental in getting me here. It also led me to meet Wim van Dalen, head of STAP, who suggested this extraordinary professorship many years ago. And, thank you to many colleagues in the audience who have welcomed me in Maastricht, and who work with me on the European projects, amongst others, Ronald Knibbe, Paul Lemmens, Jon Metsemakers, Dike van der Mheen, Gaby Ronda, Ben Steenkiste and Trudy van der Weijden.

And, to close, I would like to thank all of you for listening to my inaugural lecture as Professor of Alcohol and Health at Maastricht University. 


\section{References}

Anderson P. Alcohol consumption of undergraduates at Oxford University. Alcohol and Alcoholism, $1984,19,77-84$.

Anderson, P. \& Baumberg, B. Stakeholders' views of alcohol policy. Nordic Studies on Alcohol and Drugs 2006a 23 393-414.

Anderson, P. and Baumberg, B. Alcohol in Europe: A public health perspective. London: Institute of Alcohol Studies, 2006b.

Anderson, P. (2012a). The UK government's alcohol strategy. Drugs: education, prevention and policy, DOI: 10.3109/09687637.2012.698425.

Anderson, P. A safe, sensible and social AHRSE: New Labour and alcohol policy. Addiction 2007; 102 $1515-1521$.

Anderson, P. The impact of alcohol on health. In eds. Anderson, P., Møller, L. \& Galea, G. Alcohol in the European Union. Copenhagen, Denmark: World Health Organization, 2012b.

Anderson, P., Gula, A. \& Karlsen, JE (Submitted for publication).Taxonomy for a Global Addiction Footprint.

Anderson, P., Harrison, O., Cooper, C., \& Jane'-Llopis, E. (2011). Incentives for health. Journal of Health Communication, 16(S2), 107-133.

Anderson, P., Suhrcke, M. \& Brookes, C. An overview of the market for alcohol beverages of potentially particular appeal to minors. London, HAPI, 2012.

Baumberg B. How will alcohol sales in the UK be affected if drinkers follow government guidelines? Alcohol \& Alcoholism 2009; 44 (5): 523-528. doi: 10.1093/alcalc/agp053

Baumberg, B. \& Anderson, P. The European Strategy On Alcohol: A Landmark And A Lesson Alcohol Alcohol. 2007; 42: 1 - 2.

Byatt, A.S. (2011) Ragnarok. Edinburgh, Canongate Books.

Casswell, S. (2012). Current status of alcohol marketing policy-an urgent challenge for global governance. Addiction 107 478-485.

Celia, C., Diepeveen, S., Ling, T. The European Alcohol and Health Forum - First Monitoring Progress Report RAND Europe for European Commission, Jan 2010

Crook, C. The good company. Economist, 22 January 2005.

Fowler, J.H., Christakis, N.A. Cooperative behavior cascades in human social networks. 2009 PNAS $20101075334-5338$

Fowler, J.H., Christakis, N.A. Dynamic spread of happiness in a large social network: longitudinal analysis over 20 years in the Framingham Heart Study. British Medical Journal 2008 337, no. a2338: 1-9

Gordon, R. \& Anderson, P. Science and alcohol policy: A case study of the EU Strategy on Alcohol. Addiction 2011106 Supplement 55-66.

Harrison, O., Hajat, C., Cooper, C., Averbuj, G., \& Anderson, P. (2011). Communicating health through Health Footprints. Journal of Health Communication, 16(S2), 158-174.

HM Government (2012). The Government's alcohol strategy. London, HM Government, 2012.

International Agency for Research on Cancer (2010). Alcohol consumption and ethyl carbamate. Lyons, International Agency for Research on Cancer. 
King, D (2011). The challenge of climate change. In: Held, D., Fane-Hervey, A. \& Theros, M. The Governance of Climate Change. Cambridge, Polity Press.

Kwan, M.L., Kushi, L.H., Weltzien, E., Tam, E.K., Castillo, A., Sweeney, C. \& Caan, B.J. (2010) Alcohol Consumption and Breast Cancer Recurrence and Survival Among Women With Early-Stage Breast Cancer: The Life After Cancer Epidemiology Study Journal Clinical Oncology 2010 vol. 28no. 29 44104416

Lancet Oncology (2011). Two days in New York: reflections on the UN NCD summit. The Lancet Oncology, Volume 12, Issue 11, Page 981, October 2011

Nature (2012). Recah out about climate change. Nature 4815.

Romeri E, Baker A, Griffiths C (2007). Alcohol-related deaths by occupation, England and Wales, 2001-05. Health Statistics Quarterly, 35:6-12.

Rosenquist, J.N., Murabito, J. Fowler, J.H. \& Christakis, N.A. The spread of alcohol consumption behaviour in a large social network. Annals of Internal medicine 2010152 426-433.

Shield, K.D., Kehoe, T., Gmel, G., Rehm, M.X. \& Rehm, J. Societal Burden of Alcohol. In eds. Anderson, P., Møller, L. \& Galea, G. Alcohol in the European Union. Copenhagen, Denmark: World Health Organization, 2012.

Smith, K. Fooks, G. Collin, J. Weishaar, H. Mandal, S. Gilmore, A. "Working the System"-British American Tobacco's Influence on the European Union Treaty and Its Implications for Policy: An Analysis of Internal Tobacco Industry Documents. PLOS Medicine. 2010. 7(1)

Sutherland WJ, Bellingan L, Bellingham JR, Blackstock JJ, Bloomfield RM, et al. (2012) A Collaboratively-Derived Science-Policy Research Agenda. PLoS ONE 7(3): e31824. doi:10.1371/journal.pone.0031824

Taylor, AJP (1991). The Origins of the Second World War. London, Penguin Books, New Edition. Wiist, W.H. (Eds.) (2010). The bottom line or public health. Oxford: Oxford University Press. World Economic Forum and World Health Organization (2011) From Burden to "Best Buys": Reducing the Economic Impact of Non-Communicable Diseases in Low- and Middle-Income Countries http://www.who.int/nmh/publications/best buys summary.pdf.

World Health Organization. Global Status Report on Alcohol and Health. Geneva, Switzerland: World Health Organization, 2011.

Zaridze D, Brennan P, Boreham J, Boroda A, Karpov R, Lazarev A, Konobeevskaya I, Igitov V, Terechova T, Boffetta P, Peto R: Alcohol and cause-specific mortality in Russia: a retrospective casecontrol study of 48,557 adult deaths. Lancet 2009, 373: 2201-14. 